Original Research Paper

\title{
The Unbelief Thinking among Muslim Youth in Malaysia
}

\author{
${ }^{1}$ Norsaleha Mohd. Salleh, ${ }^{2}$ Ahmad Munawar Ismail, \\ ${ }^{1}$ Noor Hafizah Mohd. Haridi, ${ }^{1}$ Zainora Daud and ${ }^{1}$ Abur Hamdi Usman \\ ${ }^{1}$ Department of Usuluddin, International Islamic University College Selangor, Malaysia \\ ${ }^{2}$ Department of Theology and Philosophy, The National University of Malaysia, Malaysia
}

Article history

Received: 26-10-2015

Revised: 29-01-2016

Accepted: 01-02-2016

Corresponding Author: Abur Hamdi Usman,

Department of Usuluddin, International Islamic University College Selangor, Malaysia Email: aburhamdi@kuis.edu.my

\begin{abstract}
The unbelief thinking is a term that refers to the absence of adherence to religion in the context of free lifestyle practice which is centred on human rights and it also includes an understanding that is rooted in humanism, secularism, pluralism and liberalism. In relation to this, a research was conducted to identify the level of unbelief thinking among Muslim youth in Malaysia which based on the following domains: Knowledge, perception and their attitude towards humanism, secularism, pluralism and liberalism. The questionnaire was constructed by a group of researchers and its content was validated by a panel of experts. This instrument was distributed to 380 respondents in 12 of the Higher Learning Institutions in Selangor, Malaysia. The reliability of the research instrument was valued based on Cronbach's Alpha; it obtained a high result of $\alpha=$ 0.88 . The study outcomes demonstrated the mean score for the overall level of unbelief thinking among Muslim youth was low (mean $=2.21$, sd = 0.41 ). Whereas the mean score for knowledge constructs was high (mean = 3.76 , $\mathrm{sd}=1.03$ ), the mean score for perception constructs was low (mean = $2.18, \mathrm{sd}=0.65)$ and the mean score for attitude constructs was also low (mean $=1.45, \mathrm{sd}=0.48)$. Additional this study was also conducted to measure the level of their Islamic knowledge. The study showed the mean score for the level of the youth's Islamic knowledge was high (mean = $4.89, \mathrm{sd}=0.43$ ). The findings revealed the level of Islamic understanding among Muslim youth was high compared to the level of their unbelief thinking, which was low. These findings portrayed despite the existence of a small number of Muslim youth who have deviated from being adherent to religion; there are still a large number of them in Higher Learning Institutions who understand Islamic knowledge highly.
\end{abstract}

Keywords: Unbelief, Muslim, Youth, Learning, Humanism, Malaysia

\section{Introduction}

Globalization or borderless world has directly exposed humans to myriad of worthy and corrupt circumstances. One of the societal groups that are highly affected by this process is youth. This age group has been known for their lack of wise filtering of the external elements and thus readily accepts them (Ulwan, 2003). Youth is defined as an age group between 18 to 40 years old (Wong et al., 2012); it is a challenging life phase in determining individual's lifestyle, identity and thoughts. Therefore, this group is prone to intense mind influence where it could enter into a mind via various channels such as the media, communication, Internet and et cetera. Such intensity is hard to resist except for those who are coherent in their Islamic faith and teachings.
The unbelief thought is a terminology used to describe the ideas that reject religion as a reference for man (Al-Rawy, 2009). In fact, the ideas believe in human rights and deem it should be the one that paints the present and future life without the interference of religion and Islamic law. Furthermore, the ideas reject the Qur'an and hadith (Prophetic tradition) as the Muslim's authentic references in dealing with problems of the mankind; instead, they rely entirely on human being. In this context, the unbelief idea refers to deism, no theism, agnosticism, anti-religion or secular humanism (Al-Rawy, 2009). These ideas that were originally from the West practice free lifestyle which centres entirely on human rights which on a large extent is against the teachings of Islam concept (Al-Silmy, 2009). 
The unbelief ideas were introduced by Rocco Caporale and Antonio Grumelli through their writing entitled The Culture of Unbelief. According to McKinney Jr, (1972) the ideas do not believe in the existence of God; then again, they are unable to prove His nonexistence. As if they are in the middle of crisis between faith and atheism due to the doubt within themselves. In the Malaysian context, the unbelief thought were being studied by scholars and debated among Muslim activists, nevertheless the term unbelief was rarely highlighted in the early researches. Commonly, there were plenty of researches on humanism, secularism, pluralism and such. Noticeably, the appearance of these ideas was the impact of post modernism and globalisation that were brought into the world of Islam by the West via colonialism, education and media; they were channelled through subtle mind indoctrination. The indoctrination of the Western thought in the Islam world has spread out and has successfully governed the mind of the society especially youth.

\section{Problem of the Study}

In the context of the state of Selangor, Malaysia, the characteristics of unbelief thinking can be observed through several episodes such as the statements by Sister in Islam (SIS Forum), Islamic Renaissance Front, Dialogue Project, Benz Ali's statements, the youth movement from Youth Open University (UTAM), October Fest, I Want to Touch a Dog Programme and the widely talked about K-Pop Concert.

Sister in Islam (SIS) is a non-government organisation co-founded by Zainah Anwar, Aminah Wadud and their colleagues (Mokhtar, 2015). Through their website and Facebook, SIS questions the justice of the Islamic law towards women, in similar manner to their disapproval on the lash punishment imposed by the Islamic court in Malaysia on those who are found guilty of incest. In fact, they have also questioned the lash punishment on a Muslim woman who was found guilty of intoxication despite the readily accepted punishment by the women herself. Besides those, Sister in Islam (SIS) has also defended few Muslim women who participated in beauty pageant; they in fact questioned the fatwa (an Islamic religious ruling) system which forbids the involvement of Muslim women in such competition. In addition, they clearly support the freedom of faith and Muslims who renounce their faith despite knowing that both are against the constitution of Malaysia and Islam itself. They also claimed that hijab (head cover) among the Muslim women is not a religious obligation but it is merely the culture of the Arabs.

Next is the Islamic Renaissance Front (IRF), which is an organisation led by a Muslim medical doctor, Musa
(2014). In his article, Musa (2014) argued that it is ought to be understood that a nation is not from God but it is from people. The nation must serve the entire people and not just a specific group based on their religion. It must be neutral in all aspects. It is ought to clearly state that a nation is a human product and to manage it requires human effort, not the revealed inspiration. The management of a nation lies in the political territory not in the revelation.

Meanwhile a website called Dialogue Project (Mohd. Salleh et al., 2015) which is a social interaction platform consisting of individuals such as Faisal Tehrani, Benz Ali and their associates, plentifully promotes the freedom of faith, culture and jurisprudence sects. Besides that, it also promotes the freedom to practice lifestyles such as lesbian, gay, bisexual and transgender which could affect one's identity confusion. In the meantime, another young individual by the name, Khalid Mohamad Ismath through political blogs is known for his controversial statements and actions that are against the Malaysian law. In one of his facebook status updates, he claimed he would not mind having a leader with LGBT, nonreligious or social background. What matter the most to him is that the leader fulfils the trust given by the people and the nation and does not abuse the power given. Moreover, the freedom of speech that he fights for led him to make the following statement:

"The Islamic Party (PAS) subordinates have
fought tooth and nail to defeat The
Government Party (BN), Azizan Razak
recklessly highlighted the BN youth in TV3
just now. Godammit!"

It was inappropriate to address such condemnation phrase "goddamit" to someone who is senior in terms of age and moreover to someone who is a religious scholar. It is in fact that such condemnation does not portray the personality of Eastern morality and culture.

Ali (2014) in his article published on Dialogue Project website, questioned:

"... Anyone who wishes to have a different faith from us, to have a different God from us, or refuse to believe in God like we do, is arrested and his faith is seized away?"

These are some of the statements made by various organisations as well as individuals who displayed the characteristics of thinking which are not based on religious discipline. Hence, this study aimed to see how far this pattern of thinking affects to the Muslim youth in Higher Learning Institutions in Selangor, Malaysia. 


\section{Literature of the Study}

The previous researches on unbelief thinking were conducted by scholars such as (Taha, 2005; Nor and Fadhil, 2009; Suharto, 2007; Darusalam, 1998; Ahmad, 2012; Ibrahim, 2012). However, these studies were inclined towards highlighting the theoretical and analytical aspects compared to literatures. Therefore, this study was conducted to identify several aspects in enriching the diversity of the studies and findings related to field study and quantitative research. Apart from that, it also aimed to answer the current enquiries relating to societal awareness especially among youth concerning thinking issues that are faith-threatening and also the extent of their response in terms of perception and attitude towards unbelief thinking.

The unbelief thinking was measured through these domains: Knowledge, perception and attitude. The three domains were taken into account based on Al-Ghazali (2005), who argued the internalisation of faith is identified through knowledge, heartfelt confidence or feelings and is accompanied by practice. Spilka (2003) shared similar view where he believed the study of psychology of religion is usually viewed in three aspects which are cognitive, affective and behavioural. Based on this view, Mahmood (2006) used the domain of cognitive, affective as well as behavioural in measuring the level of internalisation of Islamic education among national secondary school students. The same went for Salleh (2015) who also used the similar domains (knowledge, feelings and practice) in her study regarding the internalisation of akidah (faith) among secondary school students. On top of this, interviews conducted with religious experts supported this view where they believed that the measurement related to religion must observe these three fundamental domains which are tasawwur (cognitive), feelings and behavioural (Mahmood, 2006; Salleh, 2015).

According to Al-Rawy (2009) unbelief thinking refers to secularism which separates religion from worldly affairs. Al-Rawy (2009) further described secularism as a planned movement that strive to distract humans from the goals of the hereafter to solely worldly aims. Meanwhile a panel of authors of al-Mawsu'ah alMuyassarah lil Mazahib wa al-Adyan referred unbelief thinking to all understandings that are rooted in humanism such as secularism, liberalism, pluralism and few other ideologies. Hence, all ideas that form a rejection of God and faith are actually shaping the unbelief thinking.

Looking at humanism, it is an agenda that centres on human values in decision making. According to Mustaqim (2010) humanism is an agenda originated from Europe where it flourished during the renaissance period between the 15th and 16th century. Badri (2012) regarded humanism as a new religion embraced by the
Western society. According to Yahya (2003), humanism is a threat and an attack on religion. It is an idea that brings about a movement pivoted solely on the humanistic values which is against the teachings of Islam. This is due to the fact that this understanding clearly rejects religion and God the Creator. Humanism's earlier motive was to abolish the belief among the Christian society in the existence of God. However this way of thinking started to empower the society including the Western and European scholars to the extent they turned into humanism advocators in every field. This can be seen from a Western scholar's view who defined humanism based on the reality embraced by many humanists. According to Lamont (1997):

\begin{abstract}
"Humanism believes that nature is a whole set of realities. Material, energy and ideas are the forming stuff of the universe. Supernatural entity does not exist at all. This supernatural unrealism of the human stage shows people do not have immortal and supernatural soul. Meanwhile, at the universe as a whole, our cosmos does not have the supernatural and eternal God."
\end{abstract}

Lamont's definition illustrated that humanism places human will as the goal and centre of life. The freedom of the will becomes a subject of worship. According to Taha (2005), the government and religious rituals will only emerge when conflict arises between the wills. However with advanced technology, they are promoting globalisation and leading towards subsiding the government power and the function of religion in giving way to human will. Humanism places human as the pivot of decision which gave birth to other similar ideologies. This can be seen behind the use of suffixes for terms such as liberalism, pluralism, secularism and et cetera. Despite the different terms, the ideologies have emerged from this single humanism thought where all of them are pivoted on human will and rights in decision making. According to Salleh (2015), humanism is the principle to the birth of other ideologies such as liberalism, secularism, pluralism and others. Humanism does not only bloom in the West and Europe, but it has also swept into the mind of Muslims in Malaysia (Alias and Salleh, 2010).

The word liberal refers to liberty or the concept of freedom. According to Mill (1869), the term liberal referred to personal rights regarding life-style including sexual freedom, religious freedom, freedom of thinking and protection from the government interference in one's private life. Contextually, the feminist movement strives to liberate themselves from the religious chain claiming the religious rules tyrannise and oppress women's freedom. Al-Silmy (2009) said liberalism began to appear in the West during the renaissance period in the 15th century. This movement emerged as a response 
towards the oppression and greed committed by the church and government officials at that time. As a result, a call towards the freedom from any religious chain and regulations that are oppressing the people appeared. This movement gradually enlarging and expanding to the extent it became a new agenda of the Western power to spread out the idea into the Muslim society and culture. In the end, the movement becomes a Western colonisation agenda on the Islam world which aims to dominate the entire world.

Pluralism refers to religious pluralism and an understanding that accepts all religions as equal and no one cannot claims that his or her religion is better than others. Pluralism claims every religion can save mankind and gives them the entitlement to heaven. This understanding influences the Muslims' way of thinking and contribute to the negative implications on the Islamic faith itself (Shahran, 2012). Pluralism is also regarded as an appealing doctrine that promises peace between religious believers. However, on a careful observation, this doctrine outstandingly befools, molests the reality and dignity of mankind and is against the nature of man who desires a religion that can be the saviour of his life in this world and the hereafter (Taha, 2005). According to Mohamad (2012), the pluralism effects contributed to major implications to the Malaysian society's way of thinking such as with the emergence of disputes regarding apostasy law, the demand from certain parties to form Interfaith Commission (IFC), the birth of the ideas of shared festivities and religious rituals, the use of the word 'Allah' and the use of 'salam' (Muslim greeting phrase) by non-Muslims. Besides that, the effects of pluralism could also be seen through the campaign I Want to Touch a Dog which organised in Kuala Lumpur in 2014.

On the other hand, secularism is a concept that separates human from religion. This idea extended intensely and became the society's ritual (Alias and Salleh, 2010). It is in fact secularism is very well known among the society compared to pluralism, liberalism and humanism. This is supported by random interview conducted on 185 Muslim youths throughout Malaysia where 137 out of 185 respondents clearly knew secularism compared to only 87 respondents who knew about humanism. According to Al-Attas (1978) the terms secularism, secularisation and secular have no association at all with Islam. In fact, secularism is an explicit agenda that is against Islam where the secularisation process aims to resist Islam.

\section{Research Methodology}

The research design of the study was questionnaire; it utilised a set of Unbelief Thinking Scale questionnaire. The objective was to obtain information from different sources using different measurement tools (Wiersma,
2000; Gay and Airasian, 2003). This was a quantitative study conducted on 380 respondents consisting of Muslim youth who were studying in 12 higher learning institutions in Selangor, Malaysia. The respondents were randomly selected among Muslim youths who were either studying Islamic or non-Islamic studies. This numbers are presenting of 79, 607 higher learning institutions students in the state of Selangor.

The researchers chose Selangor as the location of the study because it has the subject and data required that are able to answer the research questions and objectives. Neuman (2007; Yusoff, 2001; Noah, 2002) suggested four factors for consideration in selecting site or location which are rich in data, unfamiliarity, appropriate and has good social network. The population of the study consisted of Muslim youths who were studying in Public and Private Higher Learning Institutions in the entire state of Selangor.

Generally, the data of the study was collected using quantitative data collection method. The required data were collected through the distribution of instrument i.e., questionnaire which was constructed by a group of researchers. The questionnaire set was divided into three sections; Section A: Respondent background; Section B: Information on Knowledge about Islam and Section C: Information on Unbelief Thinking which consists of three main constructs: Knowledge, Perception and Attitude. The three constructs were used to measure the elements of unbelief thinking which consists of the following thoughts: Humanism, secularism, pluralism and liberalism.

\section{Research Findings}

The research findings involve two aspects; the research respondents' profile and the level of unbelief thinking. The research respondents' profile is explained using descriptive analysis frequency and percentage. Meanwhile the level of unbelief thinking of the respondents is identified using descriptive analysis mean, standard deviation and percentage.

\section{Research Profile}

In identifying the research respondents' profile, a research was conducted on 380 Muslim youths who were studying in 12 higher learning institutions in Selangor as shown in Table 1.

Based on Table 1, the female respondents outnumbered the male respondents; 214 of the respondents were female $(56.3 \%)$ and the remaining $166(43.7 \%)$ respondents were male. In terms of age, almost all of the respondents (359 or $94.5 \%$ ) aged 25 years old and under; there were only 21 respondents aged 26 years old and above (5.5\%). Meanwhile, for residential location, there were 260 respondents who were from the urban area $(68.4 \%)$ and 120 
respondents were from the rural area $(31.6 \%)$. As for family income, 257 respondents stated their family income was between RM5,000 and below (67.6\%), 89 respondents stated their family income was between RM5,000 to RM9,999 (23.4\%) and 34 respondents stated their family income was between RM10,000 and above $(8.9 \%)$.Meanwhile, for the field of study, 161 respondents stated theirs were Islamic Studies (42.4\%) and the remaining number of 219 respondents stated their field of study were non-Islamic studies $(57.6 \%)$.

The profile research was continued in order to identify the followings: The respondents' internalisation of Islam in their life, Sijil Pelajaran Malaysia (SPM) examination Islamic Studies grade, the degree of respondents' concern towards religious lectures and the medium used by the respondents in gaining Islamic knowledge as shown in Table 2.

Table 2 shows 307 respondents were concerned about the internalisation of Islam in their life (80.8\%), 71 respondents were less concerned $(18.7 \%)$ and only two respondents were not concerned about the internalisation of Islam in their life $(0.5 \%)$. The questionnaire findings also revealed that 241 respondents obtained an A grade in SPM Islamic Studies (63.4\%). 107 respondents obtained a B grade (28.2\%), 29 respondents obtained a $\mathrm{C}$ grade $(7.6 \%)$ and three respondents obtained a D grade $(8 \%)$. Referring to the respondents' inclination towards following religious lectures, the findings showed 234 respondents were concerned $(61.6 \%), 140$ respondents were less concerned $(36.8 \%)$ and just six respondents stated they were not concerned $(1.6 \%)$. As for the medium used to obtain Islamic knowledge, 144 respondents obtained it from social/electronic media $(37.9 \%), \quad 133$ respondents obtained it from books/magazines/newspapers (35\%). Another 39 respondents obtained it from seminars/courses/workshops (10.3\%), 32 respondents obtained it from friends $(8.4 \%)$ and 32 respondents obtained it from other sources $(8.4 \%)$.

\section{The Level of Unbelief Thinking}

The level of unbelief thinking was divided into three domains: Level of knowledge, perception and attitude as shown in Table 3.

Table 3 above shows the overall level of unbelief thinking among the respondents was low (mean = 2.21 , sd $=0.41)$, the mean score for knowledge about unbelief thinking was moderately high (mean $=3.76$, $\mathrm{sd}=1.03)$. Meanwhile, the result of the perception domain was moderately low $($ mean $=2.18, \mathrm{sd}=0.65)$ and the attitude domain was low (mean $=1.45$, $\mathrm{sd}=$ 0.48). This showed that the respondents have moderately high knowledge in the unbelief thinking elements such as humanism, liberalism, secularism and pluralism. However the respondents' perception and attitude towards the unbelief thinking showed a moderately low mean score. The condition showed the respondents are aware and are less influenced by the unbelief thinking. This can be observed through the responses given to the questionnaire distributed. The questionnaire analysis results showed the level of respondents' knowledge in the unbelief elements influence the degree of their perception and attitude. Nevertheless, these findings are still worrisome as there were respondents who either consciously or unconsciously being influenced by the unbelief symptoms. This fact was proven by the mean score of the two domains which are respondents' perception (mean $=2.18)$ and attitude $($ mean $=1.45)$ towards the elements of unbelief thinking. The study was also conducted on the respondents to identify their level of the Islamic knowledge on a general basis. The data showed the level of respondents' Islamic knowledge is high (mean $=4.89$, sd $=0.43$ ), compared to the level of respondents' unbelief thinking, it scored a low mean score $($ mean $=2.21$, $\mathrm{sd}=0.41)$.

The study was also conducted to determine the level of unbelief thinking based on the category of thoughts which are humanism, secularism, pluralism and liberalism as shown in Table 4.

Table 1. Sample profile according to gender and parents' education status and standard

\begin{tabular}{llrr}
\hline Factor & Category & $\mathrm{N}$ & Percentage \\
\hline Gender & Male & 166 & 43.7 \\
& Female & 214 & 56.3 \\
Age & 25 and under & 359 & 94.5 \\
\multirow{2}{*}{ Residential location } & 26 and above & 21 & 5.5 \\
& Urban & 260 & 68.4 \\
Family income & Rural & 120 & 31.6 \\
& Below RM5,000 & 257 & 67.6 \\
Study field & RM5,000-RM9,999 & 89 & 23.4 \\
& Above RM10,000 & 34 & 8.9 \\
Total & Islamic studies & 161 & 42.4 \\
\end{tabular}


Table 2. Sample profile based on internalisation of Islam in life, SPM Islamic studies grade and religious inclination

\begin{tabular}{llrr}
\hline Factor & Category & N & Percentage \\
\hline Internalisation of Islam in life & Concerned & 307 & 80.8 \\
& Less concerned & 71 & 18.7 \\
SPM Islamic studies grade & Not concerned & 2 & 0.5 \\
& A & 241 & 63.4 \\
& B & 107 & 28.2 \\
Following religious lectures & C & 29 & 7.6 \\
& D & 3 & 8.0 \\
Medium used to obtain Islamic knowledge & E & 0 & 0.0 \\
& Concerned & 234 & 61.6 \\
& Less concerned & 140 & 36.8 \\
& Not concerned & 6 & 1.6 \\
Total & Seoks/Magazines/Newspapers & 133 & 35.0 \\
& Social/Electronic & 144 & 10.3 \\
& Media friends & 32 & 37.9 \\
& Others & 32 & 8.4 \\
\end{tabular}

Table 3. The level of youths' unbelief thinking and Islamic knowledge

\begin{tabular}{llll}
\hline Main domain & Mean & Standard deviation & Interpretation \\
\hline Unbelief thinking & 2.21 & 0.41 & Moderately low \\
Knowledge & 3.76 & 1.03 & Moderately high \\
Perception & 2.18 & 0.65 & Moderately low \\
Attitude & 1.45 & 0.48 & Low \\
Islamic knowledge & 4.89 & 0.43 & High \\
\hline
\end{tabular}

Table 4. The level of Muslim youth's unbelief thinking according to category

\begin{tabular}{llll}
\hline Category & Mean & Standard deviation & Interpretation \\
\hline Humanism & 2.19 & 0.50 & Moderately low \\
Secularism & 2.40 & 0.46 & Moderately low \\
Pluralism & 2.12 & 0.52 & Moderately low \\
Liberalism & 2.13 & 0.46 & Moderately low \\
\hline
\end{tabular}

Table 4 shows the findings for the category of unbelief thinking of the respondents. The school of thought studied is divided into four categories which are humanism, secularism, pluralism and liberalism. Based on Table 4, the highest mean score was recorded for humanism $(2.19$, sd $=0.50)$, this is followed by secularism $($ mean $=2.40, \mathrm{sd}=0.46)$, pluralism $($ mean $=$ $2.12, \mathrm{sd}=0.52)$ and liberalism $($ mean $=2.13, \mathrm{sd}=0.46)$. Nevertheless, the overall mean score for all four elements was moderately low. In short, the results revealed that the level of unbelief thinking among the respondents was moderately low compared to the high mean score for their Islamic knowledge.

\section{Discussion}

Questions about youth and religion have been central to discussions about continuity and change in every religious tradition. At the same time, the attitudes of young people towards religion throw light on the social and cultural circumstances in which they live. This is why study of youth and religion insist on making connections with central features of society such as the family, economy, education, politics, law, friendship, entertainment, gender relations, sexuality, consumerism, the media and sport (Beckford, 2010). Hence the implications of this irreligious thoughts directly affect the stability of the country and challenge the constitutionality of Malaysia where Islam is the religion of the federation.

Among the main factors that contributed to the idea of unbelief to religion is the weakness of youth in faith to God. This can be viewed from the angle of practice, prayers and recitations of the Quran which increasingly less to be practiced by youth today. Therefore, the institution of the family should be aware of the importance of religious education to their children since they were at young. As argued by Etengoff and Daiute (2013) that there has been little psychological research conducted focusing on the development of the Muslim American self, with approximately 6 to 7 million Muslims living in America within the past decade. This inquiry addresses that gap by focusing on how familial religious affiliation during childhood and the everyday environmental activity systems of emerging adulthood 
impact religious practice and the construction of the religious self among Sunni-Muslim American emerging adults $(N=63,18-29$ years $)$ via the development of diverse mediational strategies. Etengoff and Daiute (2013) found that participants' religious development emerged as a diverse and dynamic process developing in relation to the interacting activity systems and sociorelational contexts of emerging adulthood.

Finally, this study is expected to provide input to the authorities of Islam in order to carry out prevention and to strengthen the true Islamic faith of youth in Malaysia.

\section{Conclusion}

The findings show that majority of the Malaysian Muslim youths concern about Islam. This was supported by the contributing factors to the internalisation of Islam, which are the level of education, interest in following religious lectures and the role of social media. Meanwhile the youths' level of knowledge about unbelief thinking was at a very satisfactory level aligned with the moderately low level of perception and attitude. These findings demonstrated that knowledge about religion and the unbelief thinking affect the youths' perceptions and attitude towards the unbelief thinking itself. However, the moderate mean score for the youths' perception and attitude reflected an alarming level of unbelief thinking among the Muslim youth. This is supported by the findings of moderately low level of the youths' idea regarding humanism, secularism, pluralism and liberalism. This indirectly reflects that they do have knowledge about the teachings of Islam, however, their attitude and perception towards the teachings are poor which make them prone to be derailed from Islam and then renounce the religion. Thus, in response to the situation, a study suggested that the youths who are the students of Islamic studies should be responsible in ensuring the development of these current issues is dealt with the tradition of the study of Qur'an and Sunnah. This is because the attack of humanism, secularism, pluralism and liberalism can be repelled with the youth's strength in their identity and attitude towards Qur'an and Sunnah.

\section{Acknowledgement}

We would like to thank to International Islamic University College Selangor (KUIS) as a funder to this research and all of the humble contributors for their valuable help in the construction of this research.

\section{Funding Information}

The funder of this research is under KUIS research grants, 2015/P/GPIK/GPM-003.

\section{Author's Contributions}

Norsaleha Mohd. Salleh: Designed the research plan, organized the study and contributed to the writing of the article.

Ahmad Munawar Ismail: Develop the methodology used in this study.

Noor Hafizah Mohd. Haridi: Create discussion and correcting references and article review.

Zainora Daud: Collect and process secondary data.

Abur Hamdi Usman: Process the table data and review the article.

\section{Ethics}

The authors would be responsible for any issues that may arise after the publication of this manuscript.

\section{References}

Ahmad, I.M., 2012. Religious pluralism issues: The devil movement in renouncing the ummah. Muafakat, Kuala Lumpur.

Al-Attas, S.M., 1978. Islam and secularism. Muslim Youth Movement of Malaysia, Kuala Lumpur.

Al-Ghazali, A.H., 2005. Ihya' ulum al-din. Cairo, Dar alTauzi'.

Alias, R. and N.M. Salleh, 2010. Al-Banna thought and western ideology: The clash of two agendas. Paper presented in Hassan al-Banna convention in paving the nation agenda. Universiti Tenaga Nasional (UNITEN), Putrajaya Campus.

Al-Rawy, F.H., 2009. Al-Fikr al-islamy fi muwajahah alfikr al-gharby. Oman: Dar al-Makmun.

Al-Silmy, A.R., 2009. Haqiqat al-libraliyah wa mawqif al-Islam minha. Mecca.

Badri, M., 2012. Seminar on homosexual and gender from the Islamic and psychological perspective. Ibn Khaldun University.

Beckford, J.A., 2010. Foreword. In: Religion and Youth, Collins-Mayo, S. and P. Dandelion (Eds.), Ashgate Publishing, Ltd, Farnham, ISBN-10: 140940725X.

Ali, B., 2014. ADA APA Dengan Tuhan. Projek Dialog.

Darusalam, G., 1998. Islam and western ideology. Utusan Publication, Kuala Lumpur.

Etengoff, C.M. and C. Daiute, 2013. Sunni-Muslim American religious development during emerging adulthood. J. Adolescent Res., 28: 690-714. DOI: $10.1177 / 0743558413477197$

Gay, L.R. and P.W. Airasian, 2003. Educational Research: Competencies for Analysis and Applications. 8th Edn., Pearson Merrill Prentice Hall, Upper Saddle River, ISBN-10: 0131185349, pp: 614.

Ibrahim, M., 2012. Liberal Islam issues and the reactions. Islamic Religion Department of Selangor.

Lamont, C., 1997. Philosophy of humanisme. HalfMoon Foundation, Inc. 
Mahmood, A., 2006. The measurement of the level of internalization of Islamic education among national secondary school students in Malaysia. PhD Thesis, Faculty of Education.

McKinney Jr, W.J., 1972. Reviewed work: The culture of unbelief by ROCCO Caporale, Antonio Grumelli. J. Rev. Religious Res., 14: 47-50.

Mill, J.S., 1869. On Liberty. 6th Edn., Longmans, Green, Reader and Dyer, Canada, pp: 223.

Mohamad, Y., 2012. The Threat of Religious Pluralism in Malaysia: An Early Observation. In: Religious Pluralism, the Devil's Movement to Renounce the Ummah. Mina, I. (Ed.), Muafakat, Kuala Lumpur

Mohd. Salleh, N., A.M. Ismail, N.H.A.M. Haridi and Z. Daud, 2015. Pemikiran tidak beragama dalam kalangan Belia Islam Di Malaysia. Satu Kajian Rintis. J. Islam dan Masyarakat Kontemporari, 11: 40-55.

Mokhtar, R.H., 2015. The History of Feminist Movement. In: Women and the Challenge of Globalisation, Misran, N. (Ed.), Konwanis Consultancy, Putrajaya.

Musa, A.F., 2014. The Never Ending Chase of Islamic Nation. In: Reformist Thought Discourse, Musa, A.F. (Ed.), Islamic Renaissance Front, Kuala Lumpur.

Mustaqim, A.H., 2010. Humanism in the Abdur Rahman Wahid's Thoughts. MSc Thesis, Sunan Kalijaga University.

Neuman, W.L., 2007. Social Research Methods. 6th Edn., Pearson Education India, New Delhi, ISBN-10: 8131714640, pp: 604.

Noah, S.M., 2002. Research design: The philosophy, theory and practice. Putra Malaysia University.
Nor, R.M. and A.A. Fadhil, 2009. Liberal Islam and religious pluralism. Jundi Resources, Kuala Lumpur.

Salleh, N.M., 2015. Internalization of faith, heart and spiritual tranquillity of national secondary school students in Malaysia. PhD Thesis, Faculty of Education.

Shahran, M.F., 2012. Islamic Faith and Religious Pluralism. In: Religious Pluralism, the Devil's Movement to Renounce the Ummah, Mina, I. (Ed.), Muafakat, Kuala Lumpur.

Spilka, B., 2003. The Psychology of Religion: An Empirical Approach. 1st Edn., Guilford Press, New York, ISBN-10: 1572309016, pp: 671.

Suharto, U., 2007. The liberal thinking of Liberal Islam. Fajr Publication.

Taha, A.M., 2005. Al-Ta'adudiyah al-diniyah ru'yah Islamiyah. Gombak, IIUM.

Ulwan, A.N., 2003. Child education in Islam. National Publication, Singapore.

Wong, F.V., M.Y. Lee, X.R. Lin and S.Y. Low, 2012. A study on the youth attitude toward purchase green products in Malaysia and Singapore. UTAR Institutional Repository.

Wiersma, W., 2000. Research Methods in Education: An Introduction. 7th Edn., Allyn and Bacon, Boston, ISBN-10: 0205284922, pp: 476.

Yahya, H., 2003. Global Freemasonry. 1st Edn., Global Publishing, Istanbul, ISBN-10: 9756426004, pp: 191.

Yusoff, M., 2001. Qualitative research: Field study work experience. Universiti Malaya Publication. 